\title{
2. SEISMIC CHARACTERISTICS OF A LATE TRIASSIC CARBONATE REEFAL PLATFORM ON THE WOMBAT PLATEAU, AUSTRALIA ${ }^{1}$
}

\author{
Paul E. Williamson ${ }^{2}$
}

\begin{abstract}
At Site 764 of ODP Leg 122 on the Wombat Plateau (northernmost Exmouth Plateau), $210 \mathrm{~m}$ of Upper Triassic (Rhaetian) reefal complex was cored. This represents the first discovery of Triassic reefal material in the region of the Australian Northwest Shelf. Paleogeographic considerations suggest that Late Triassic reefs may be common elsewhere along the outer continental shelf and slope of the Northwest Shelf.

The seismic sequences associated with the Rhaetian reefal interval on the northeastern flank of the Wombat Plateau are analyzed in relation to core samples from Sites 764 and 761 , with a view to establishing the seismic characteristics of the reefal complex and the probability of the occurrence of other such complexes and investigating the history and depositional environments of the Rhaetian carbonate platform.

Seismic-reflection data through Site 764 show that the reefal complex corresponds predominantly to a seismically poorly reflective zone. Traceable seismic horizons, which pass with reduced amplitude through the complex, correspond to regional unconformities formed by periods of erosion or nondeposition. Seismic facies around the flanks of the complex at Site 764 are consistent with the deposition of wedges of prograding reef-derived detritus or aprons of carbonate sediment deposited by current enhancement around the complex and with channeling and the formation of mounds or ridges near the complex. A comparison of features in the seismic-reflection data from the Wombat Plateau with the seismic characteristics of the reef complex at Site 764 suggests that there is probably a major Late Triassic carbonate reefal platform beneath the Wombat Plateau. Furthermore, many pinnacle reef complexes apparently developed on the northeastern margins of the plateau at that time.

Seismic-reflection data tying Sites 764 and 761 allows the definition of three main seismic sequences separated by well-developed unconformities and associated with carbonate platform development in the Rhaetian. The lowest sequence (sequence A) contains seismic features that probably correspond to reefal complexes, reef-associated ramps of sediment, and channeling and formation of mounds or ridges in an open marine environment. Sequence B is similar in character to sequence $\mathrm{A}$ in the north. Its parallel reflection configuration in the south corresponds to a change from an open marine to lagoonal environment near Site 761. Sequence $C$ displays gentle progradation to the north and is truncated between Sites 764 and 761 . Although seismic sequences A, B, and C can be defined, their identification in sequence stratigraphic terms is more problematical due to relatively small amount of data. The geological data at Sites 761 and 764 suggest that sequence A may represent a transgressive systems tract, and sequences $\mathrm{B}$ and $\mathrm{C}$ represent highstand and transgressive systems tracts, respectively.
\end{abstract}

\section{INTRODUCTION}

Leg 122 of the Ocean Drilling Program (ODP) was undertaken over the Exmouth Plateau in July and August 1988 aboard JOIDES Resolution. During the leg about $3.5 \mathrm{~km}$ of drilling was carried out at six sites (Fig. 1); two sites (762 and 763) are on the central Exmouth Plateau and four (Sites 759, 760,761 , and 764) are on a northern subplateau of the Exmouth, the Wombat Plateau. At Site $764,210 \mathrm{~m}$ of Rhaetian reefal complex on the northernmost Wombat Plateau was cored, the first documented discovery of Triassic reefal material near the Australian Northwest Shelf. At Sites 759, 760, and 761 nonreefal Upper Triassic shelf carbonates and deltaic sediments were recovered.

Preliminary results relating to the Upper Triassic carbonates have been described by Williamson et al. (1989) and Exon et al. (1989). The facies distribution and seismic expression of carbonate reefal platforms have been described for the Tertiary of northeastern Australia by Davies et al. $(1988,1989)$, for the Devonian of the Canning Basin of northwest Australia by Playford (1984), and for the Permian and Jurassic of

\footnotetext{
${ }^{1}$ von Rad, U., Haq, B. U., et al., 1992. Proc. ODP, Sci. Results, 122: College Station, TX (Ocean Drilling Program).

2 Bureau of Mineral Resources, P.O. Box 378, Canberra, ACT, 2601 Australia.
}

southern North America by Sarg (1988). The terminology used to describe carbonate platforms and reefs is somewhat varied and inconsistent. Consequently, the classification scheme adopted here conforms to that of Playford (1984).

The Northwest Shelf northeast of the Exmouth Plateau lay at the southern margin of a warm Tethys Ocean at a paleolatitude of $25^{\circ}-30^{\circ} \mathrm{S}$ during Rhaetian time (Scotese, 1986; Kharmov, 1987). Carbonate reefs at the northern margin of the Tethys Ocean have been studied by Flügel and Stanley (1984), and the dynamics of the associated carbonate platforms were discussed by Bosellini (1989). These carbonate platforms occur in the European Alps, but a restored Late Triassic section shows the development of reefal complexes on the margin of the carbonate platform (Bosellini, 1989), analogous to the situation represented by Site 764 on the Wombat Plateau.

Seismic-reflection coverage of the Wombat Plateau consists largely of single-channel reconnaissance data shot using the RV Sonne in 1979 (von Stackelberg et al., 1980) and 120 $\mathrm{km}$ of multichannel data, consisting of both regional and site-survey lines (Exon and Williamson, 1988), collected with the RV Rig Seismic. Additional single-channel data utilizing an 80 -in. ${ }^{3}$ water gun were collected aboard JOIDES Resolution to locate drill sites and to provide additional regional data (Haq, von Rad, O'Connell, et al., 1990; Fig. 2). Site 764 was located on ODP line 122-6B.

Although the frequency content of the ODP water gun data is lower than expected because of the excessive depths at 


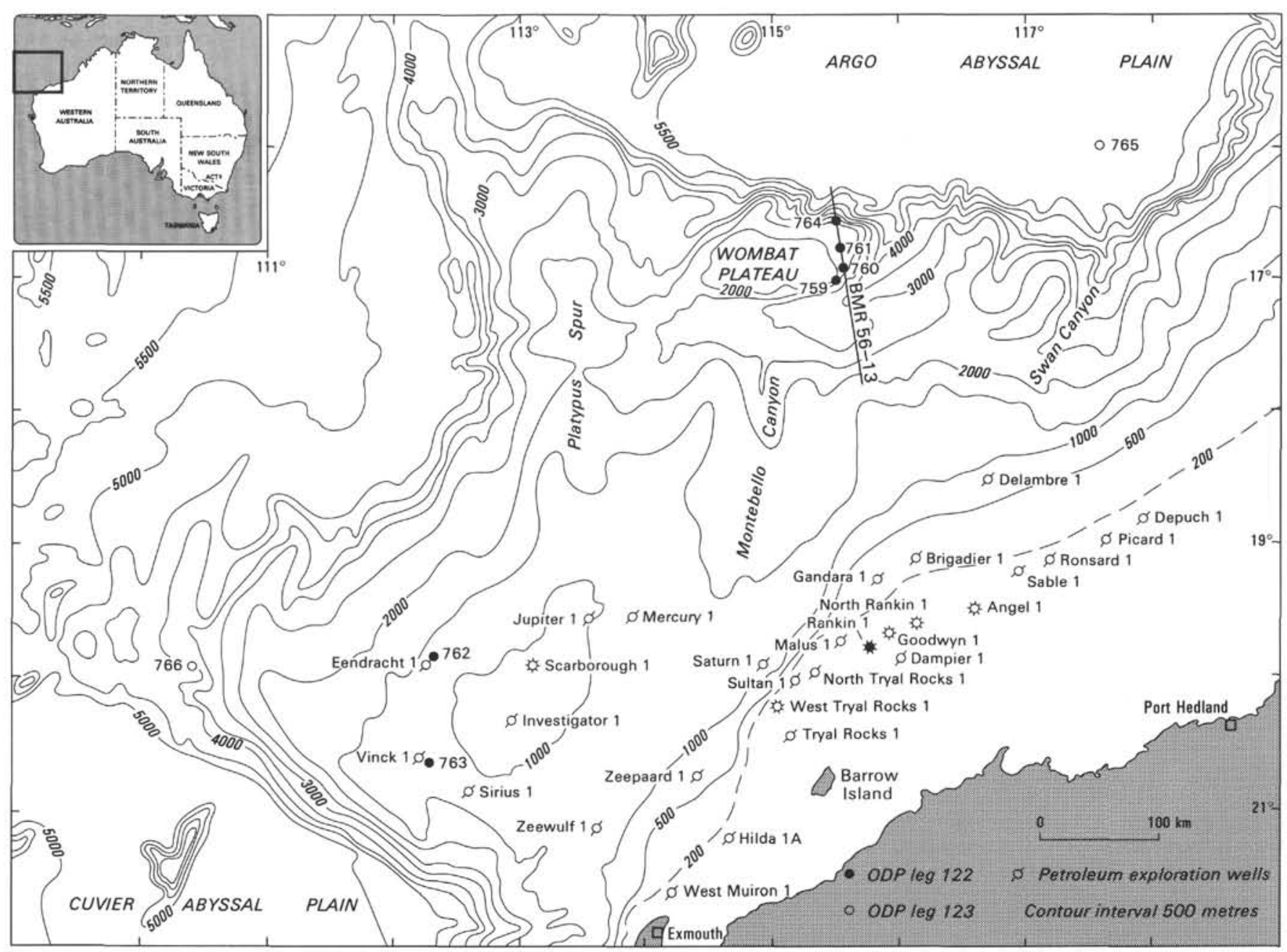

Figure 1. Location of Leg 122 sites on the Exmouth and Wombat plateaus.

which the guns and detector cable were towed, it is higher than that of the conventional seismic-reflection data in the area. The single-channel water gun data were processed at the Bureau of Mineral Resources (BMR) processing center in Canberra, using spatially averaged spiking deconvolution, which significantly reduced pulse length, and filtered prior to display. Global positioning system (GPS) navigation was not available for the approach to Site 764 and the tie to ODP line $122-6 \mathrm{~B}$ was predicated on the assumption that the site location was the same as the location of the beacon drop, which is valid within about $150 \mathrm{~m}$ for sites navigated with GPS (Williamson and Shipboard Scientific Party, 1990).

Site 764 provides the ground truth in the definition of the seismic characteristics of the Rhaetian reefal complexes. These characteristics have been sought on seismic-reflection profiles from the Wombat Plateau to deduce the existence of other reefal complexes in the area. In addition, the seismicreflection data tying Sites 761 and 764 have allowed seismic sequences to be traced throughout the area and have enabled an investigation of the environments of deposition and the development of the Rhaetian carbonate platform.

The interpretation of seismic profiles discussed in the following, combined with the well data, suggests that there is a series of Rhaetian reefal complexes on the eastern Wombat Plateau, surrounded by carbonate wedges. The reefal complexes are interbedded with nonreefal lagoonal and shelf carbonates of various types. Deltaic sediments like those in the Carnian and Norian (Haq, von Rad, O'Connell, et al., 1990) are not present in the Rhaetian. The broad variations in seismic character can be related to changes of depositional environment at Sites 764 and 761 .

\section{REGIONAL SETTING}

The Exmouth Plateau is $600 \mathrm{~km}$ long by $350 \mathrm{~km}$ wide, with water depths ranging from 800 to $4000 \mathrm{~m}$ (Fig. 1). The geological development of the plateau has been discussed by many authors, including Falvey and Veevers (1974), Veevers and Johnstone (1974), Veevers and Cotterill (1979), Powell (1976), Willcox and Exon (1976), Larson (1977), Exon and Willcox $(1978,1980)$, Wright and Wheatley (1979), Larson et al. (1979), von Stackelberg et al. (1980), Falvey and Mutter (1981), Barber (1982, 1988), Willcox (1982), von Rad and Exon (1983), Exon and Williamson (1988), Williamson and Falvey (1988), Mutter et al. (1989), and Williamson et al. (1990). The plateau consists of rifted and deeply subsided continental crust covered by a Phanerozoic sedimentary sequence about $10 \mathrm{~km}$ thick. It is bounded to the west and south by the Gascoyne and Cuvier abyssal plains, respectively, and to the north by the Argo Abyssal Plain. The oceanic crust of the Argo Abyssal Plain is slowly being consumed by the convergence of Australia with the Sunda and Banda arcs. The northern Exmouth Plateau margin separated from a continental fragment to the north in the Late Jurassic. Major horst and graben development in the Jurassic and Early Cretaceous, 


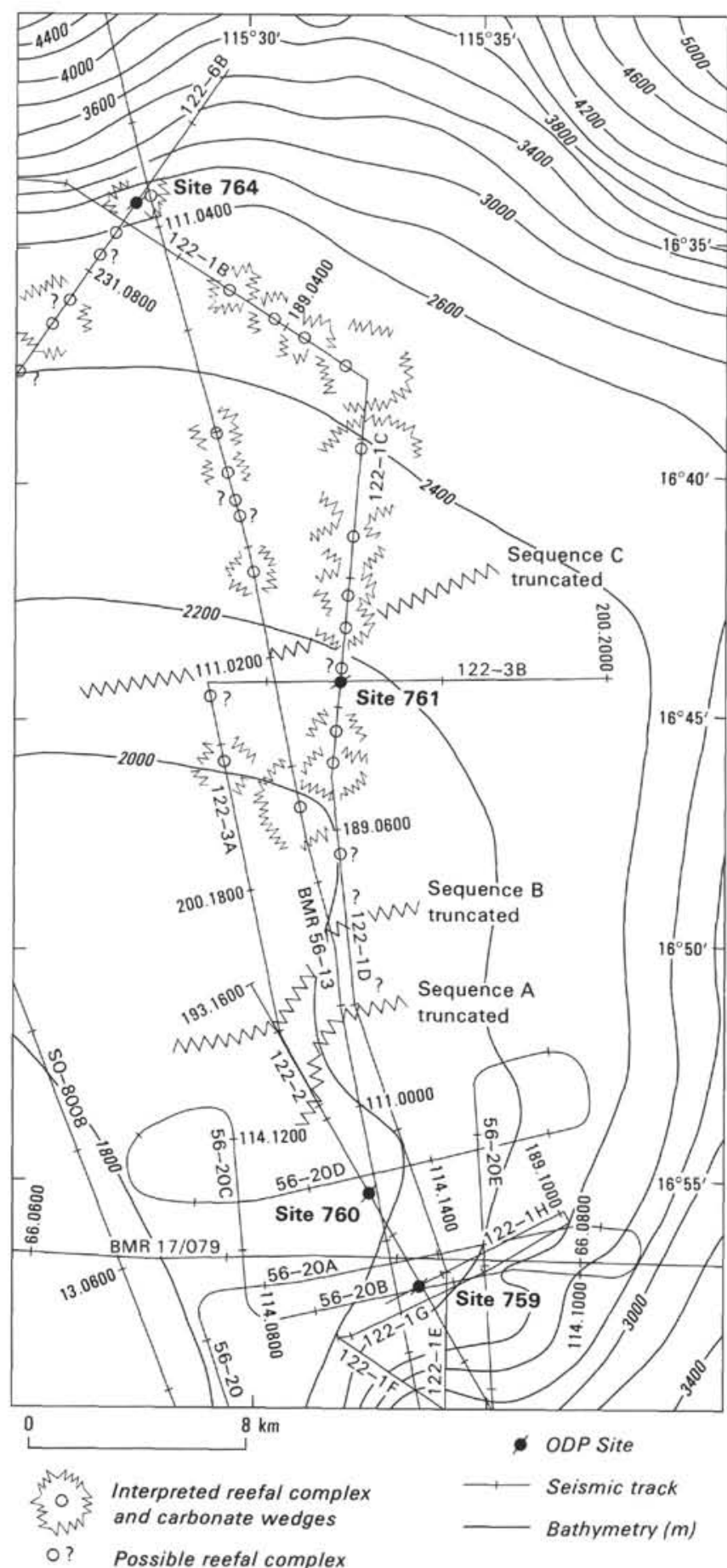

Figure 2. Map showing the location of Sites 764 and 761, BMR seismic-reflection line 56-13, and ODP lines 122-1, 122-3, and 122-6 on the Wombat Plateau.

followed by Cretaceous subsidence north of an east-west hinge line, resulted in the formation of the Wombat Plateau (Fig. 1).

\section{PALEOGEOGRAPHY}

In the Late Triassic, present-day northwest Australia faced northward and lay at $25^{\circ}-30^{\circ} \mathrm{S}$ (Scotese, 1986; Kharmov, 1987). It was the northern margin of the supercontinent of Gondwanaland, separated from Laurasia by the equatorial
Tethyan Ocean (Şengör, 1985). The waters of the Tethyan Ocean were tropical to subtropical in the Late Triassic, and reef growth abounded (Stanley, 1987). Hexacorals had emerged as the dominant reef builders in the mid-Triassic (about $220 \mathrm{Ma}$ ), after the late Permian extinction; they were a new coral group, the ancestors of today's reef-building corals. The breakup of northern Gondwanaland in the Late Jurassic (Veevers and Johnstone, 1974; von Rad and Exon, 1983) was followed by the rifting of continental fragments away to the north to join East Asia. There is considerable evidence that reefs are still preserved in and near northern Australia. Upper Triassic reefal carbonate rocks occur in East Indonesia on continental fragments thought to have been part of Gondwana in the early Mesozoic (Tjokrosapoetra and Budhitrisna, 1982; Pigram and Panggabean, 1984) and in Papua New Guinea (Bain et al., 1975; Skwarko et al., 1976).

\section{UPPER TRIASSIC CARBONATE ROCKS ON THE WOMBAT PLATEAU}

Shelf carbonates, ranging in age from Late Triassic to Middle Jurassic, were dredged from the northern margin of the Exmouth Plateau (including the Wombat Plateau) using the RV Sonne (von Stackelberg et al., 1980) and RV Rig Seismic (Exon and Williamson, 1988). The existence of these carbonates led to the drilling of four ODP sites on the eastern Wombat Plateau (Fig. 2). Their relationship to the BMR seismic profile 56-13 is shown in Figure 3; the holes penetrated older Late Triassic sequences in the south and younger ones in the north. The Triassic sequences were fully cored. Recovery was excellent in detrital sequences, but was only about $20 \%$ in carbonates. Wireline logs showed that these sequences were very homogeneous, so that the rocks recovered are representative of the sequences drilled. The lithology encountered is reviewed in Haq, von Rad, et al. (1990).

A composite stratigraphic section based on the Wombat Plateau drilling that combines the lithology derived from the best developed sequences in the four holes is shown in Figure 4. The composite maximum thickness of the Upper Triassic sediments in the four wells is about $900 \mathrm{~m}$. Unconformities separate this section into lower to middle Carnian, upper Carnian, Norian, and Rhaetian sequences. The lower to middle Carnian sequence is more than $180 \mathrm{~m}$ thick and consists of prodelta mudstones overlain by deltaic, marginal marine, and nonmarine mudstone and coal and associated carbonate shoals. The upper Carnian sequence is $90 \mathrm{~m}$ thick and consists of distal prodelta mudstone shallowing upward to proximal prodelta mudstone and carbonate banks. The Norian sediments are $330 \mathrm{~m}$ thick and consist of a number of shallowing-upward sequences deposited in a variety of shallow marine, paralic, and coastal plain environments. Mudstones predominate, both marine and nonmarine, and the associated lithology includes shelf carbonates, sandstone, and coal, with soil profiles near the top.

The Rhaetian interval consists predominantly of shelf carbonates, including reef complex. A reef complex was drilled only at Site 764 (Fig. 3), where the 300-m-thick sequence consists of outer shelf mudstone, overlain by cycles of outer shelf limestone and marl, overlain by a thick sequence of alternating reefal, perireefal, and back-reefal deposits including oolite shoals and fore-reef talus, and capped by shallow, open marine limestone and marl.

The oldest sediments recovered at Site 764 from 294.5 to $280.1 \mathrm{~m}$ below seafloor (mbsf) consist of very dark, clayey, partly recrystallized marlstone to wackestone. These rocks are interbedded with light gray carbonate mudstone containing clay. Palynomorphs indicate a Rhaetian age. Crinoid fragments are common in the clayey carbonate mudstone, 

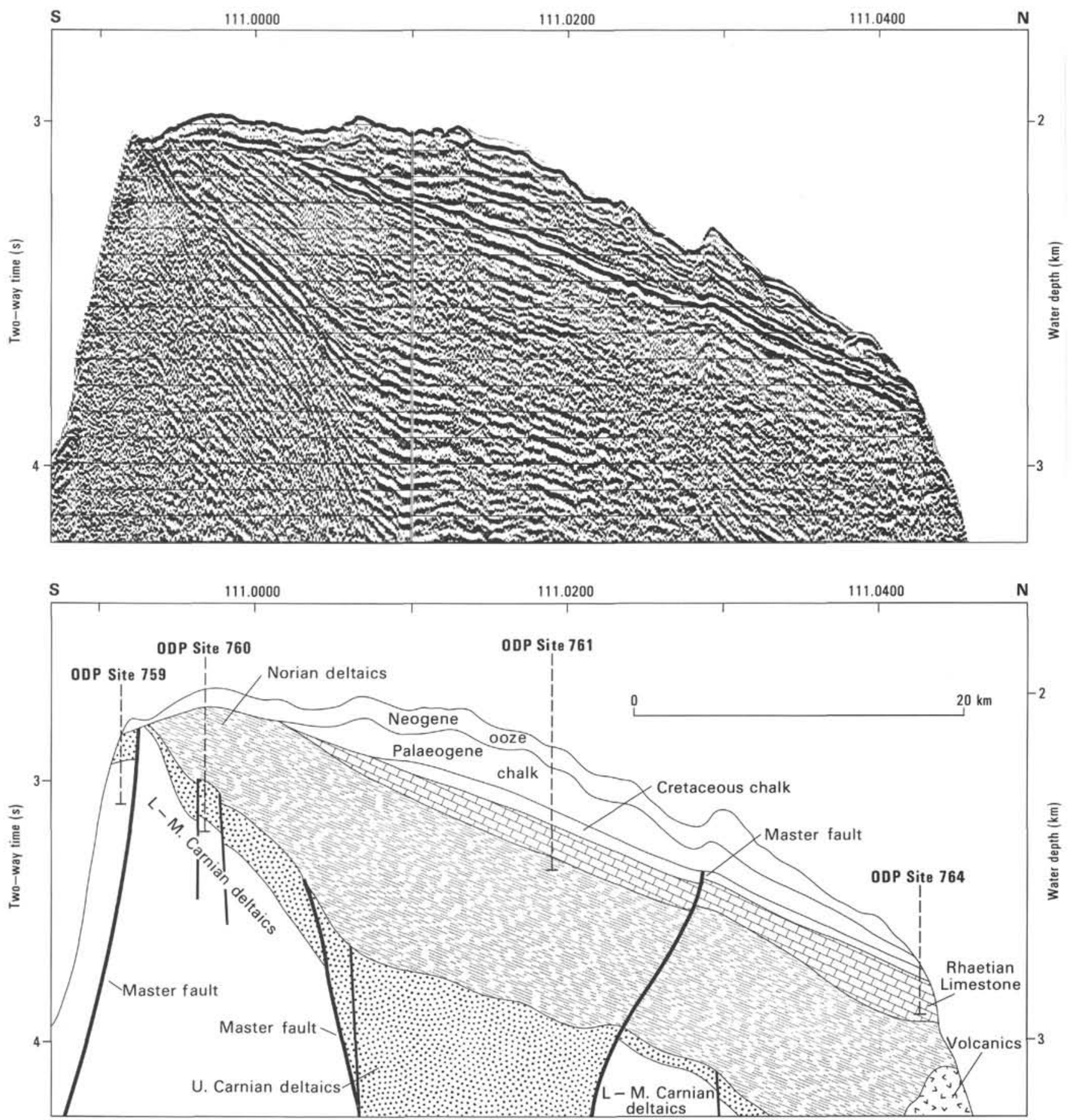

Figure 3. Regional north-south BMR seismic line 56-13, showing a cross section of the Wombat Plateau and the projected locations of Sites $759,760,761$, and 764. Location shown in Figures 1 and 2.

which may indicate an open marine, deeper water (lower photic zone) environment. The extensive bioturbation suggests a nutrient-rich substratum and/or slow sedimentation rates and possibly a lagoonal to back-reef mud flat environment. The environment was certainly open marine and lowenergy lagoonal (back reef) or deeper marine (deeper fore-reef slope, as indicated by the presence of crinoids).

The 210-m-thick reefal to perireefal sequence (280.1-72.5 mbsf), of which less than $10 \%$ was recovered, consists of a great variety of shallow-water platform limestones and related lithology, with well-preserved reefal framework structures (sponge and coral boundstones). Major lithologic types include wackestone, packstone, grainstone, rudstone, and boundstone. Dominant fossil groups represented include colonial hermatypic scleractinian corals, sponges, pelecypods, brachiopods, echinoderms, and foraminifers; minor fossil groups identified are green algae, bryozoans, and gastropods (Haq, von Rad, O'Connell, et al., 1990). The prevalent in-situ sessile benthic fossils, such as colonial corals and green algae, are characteristic in Tethyan Late Triassic reefs (Flügel and 
LATE TRIASSIC CARBONATE PLATFORM, WOMBAT PLATEAU

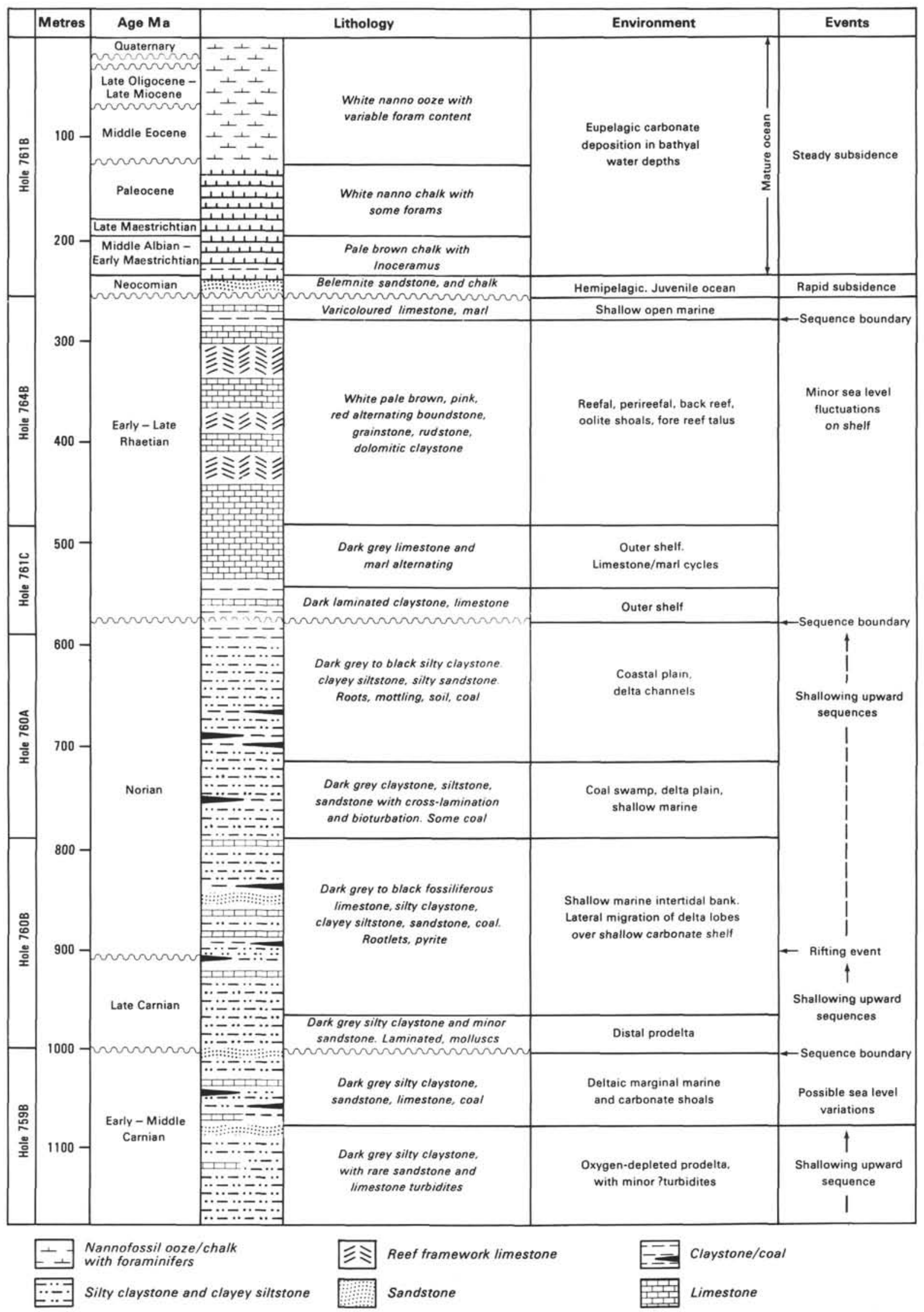

Figure 4. Composite stratigraphy of the Wombat Plateau from drilling data. 

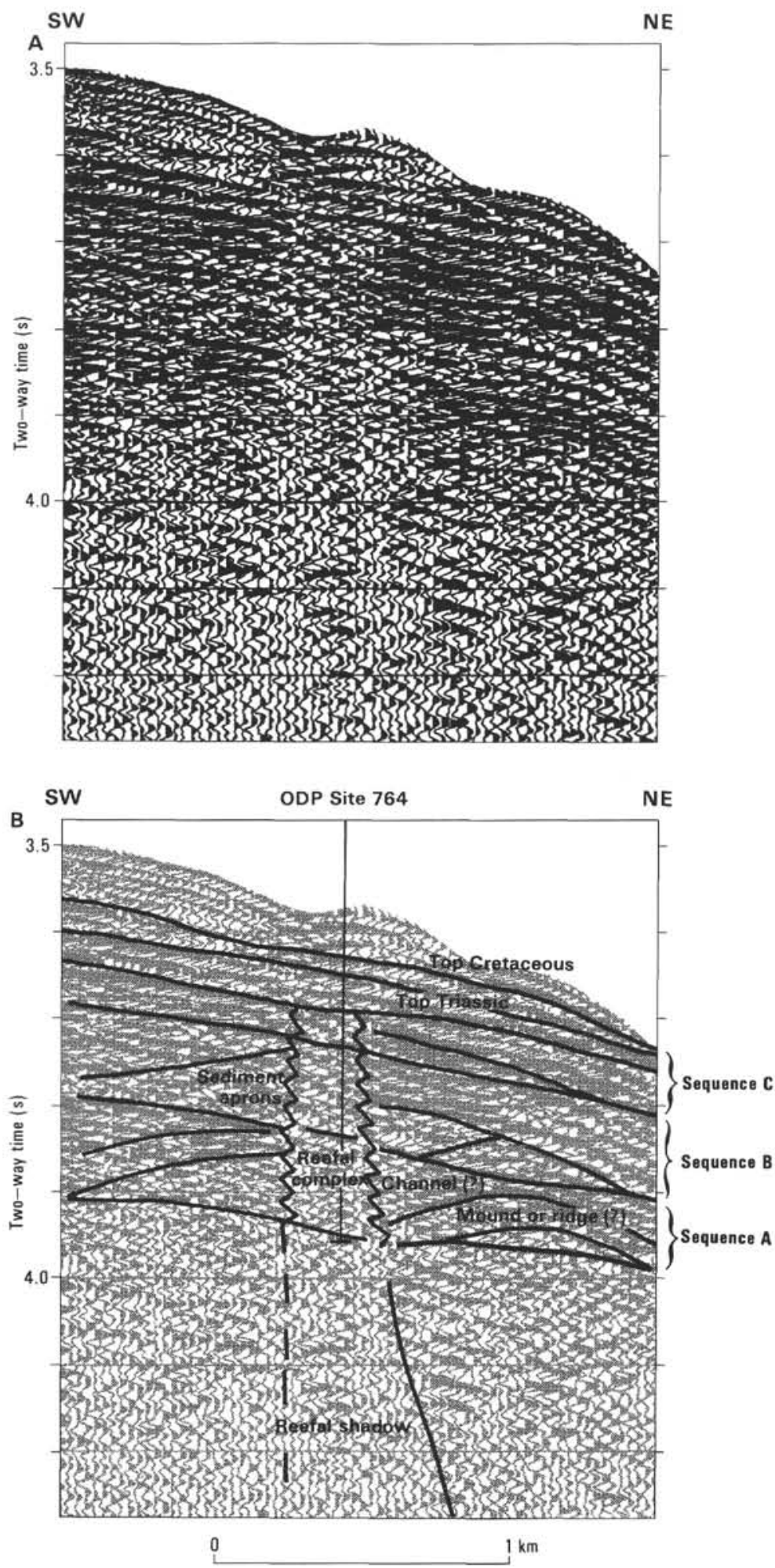

Figure 5. Uninterpreted (A) and interpreted (B) segment of northeast-directed ODP line 122-6B through Site 764 showing stratigraphic levels and seismic sequences. The reefal complex corresponds to a zone of poor reflections. Downlapping seismic facies surrounding the reefal complex are interpreted as wedges of reef-derived detrital sediments or sediment aprons deposited by currents. Location shown in Figure 6. 
Stanley, 1984). Most limestones are highly porous, with vugs filled partly by dogtooth calcite and partly by several generations of micrite and hematite-goethite.

These microfacies types signify either a highly agitated, well-oxidized carbonate bank or ramp environment or a reefal environment. The lower part of the sequence consists of bioclastic rudstone and floatstone interbedded with wackestone and mudstone. This is interpreted as talus material on a fore-reef or back-reef slope or a ramp. Preliminary analyses by Haq, von Rad, O'Connell, et al. (1990) indicate that about five depositional cycles can be identified, from the bottom upward: packstone/wackestone (in-situ deeper marine fore-reef or ramp environment); rudstone/ carbonate breccia (gravity mass-flow deposits, possibly forereef talus); white oolite grainstones (Bahamian Bank-type deposit, highly agitated); reefal boundstone/bafflestone (coral reef core buildup); grainstone, packstone, wackestone (possibly back reef, intertidal); and carbonate mudstone (intertidal, lagoonal, quiet water).

The transgressive facies at Site $764(72.5-49.3 \mathrm{mbsf})$, overlying the reefal facies, consists of gray to dark gray alternating clayey, recrystallized limestone and calcareous claystone. The depositional environment was probably open marine and below wave base (Haq, von Rad, O'Connell, et al., 1990). The overlying unit consists of lighter colored fossiliferous wackestone, packstone, and grainstone with Triasina hantkeni, a typical latest Triassic foraminifer; the wackestone and packstone are partly dolomitized. The grainstone fines upward into wackestone and carbonate mudstone. These sediments were probably deposited in a well-oxygenated, quiet to moderate-energy environment, with periodic current redeposition. Crinoids found in the wackestone and carbonate mudstone might indicate a deeper marine environment.

\section{SEISMIC CHARACTERISTICS OF REEFAL COMPLEXES}

\section{Site 764/Line 122-6B}

Reef facies were drilled at Site 764 (Fig. 5), located on ODP line $122-6 \mathrm{~B}, 3 \mathrm{~km}$ south of the northern escarpment of the Wombat Plateau and about $0.4 \mathrm{~km}$ off BMR line $56-13$, which was used for the initial definition of the site (Figs. 2 and 3).

Having obtained ground truth from the drilling, the seismic data were examined to determine the seismic characteristics of the Rhaetian reefal complex and associated strata. At Site 764 , Oligocene oozes rest on Maestrichtian chalk at 40 mbsf. The chalk is $17 \mathrm{~m}$ thick and is represented by only one cycle on the seismic-reflection profile. A relatively continuous seismic event corresponds to the main unconformity at the top of the Triassic, which, at Site 764 , overlies the Rhaetian reefal complex. The top Triassic seismic horizon has positive relief over the crest of the interpreted complex.

The interval at Site 764 that corresponds to the reefal rocks is characterized seismically by a poorly reflecting zone with a marked lack of reflector continuity compared with the areas on either side. Within this zone, some seismic horizons corresponding to unconformities can be traced. The poorly reflecting facies also seems to mask deeper events, which appear to exhibit velocity pull-up, suggesting that the velocity of the reefal material is, on average, higher than that of the alternating carbonate and marl layers that probably surround the reef. The reefal complex appears to be located on a paleohigh, on the edge of an up-faulted block.

Downlapping and parallel-layered zones occur on either side of the reefal complex (Fig. 5). The downlapping seismic facies, occurring to the northeast and southwest of the complex, are interpreted to be wedges of reef-derived detrital sediments and/or fine-grained carbonate aprons deposited by currents around the complex. The upper downlapping zone within sequence $B$ has a thickness of approximately $50 \mathrm{~ms}$ two-way traveltime (TWT) at the edge of the reefal complex and extends for approximately $1.0 \mathrm{~km}$ in either direction. Seismic horizons paralleling regional dip occur above and adjacent to the downlapping zone. In the underlying sequence $\mathrm{A}$, a second downlapping zone occurs with a maximum thickness of approximately $100 \mathrm{~ms}$ TWT and extends for approximately $0.8 \mathrm{~km}$ to the south. To the north of the reefal complex, this sequence contains apparently contrary dips within the wedge that possibly correspond to channeling and the formation of mounds or ridges. A similar but more subdued phenomenon can be observed in the overlying wedge of sequence $\mathrm{B}$. The base of the downlapping zone of sequence A coincides with the level of the base of the reefal section defined by drilling (Fig. 5).

Seismic characteristics at and near Site 764 that are apparently associated with the reefal complex can be summarized as follows:

1. a zone of low reflectivity corresponding to the reefal complex;

2. velocity pull-up below the complex;

3. blanking of seismic energy below the complex;

4. positive relief above the complex;

5. location of the low-reflectivity zone above a paleohigh;

6. downlapping seismic facies adjacent to the reefal complex, which probably represent either prograding wedges of reef-derived detritus or aprons of carbonate sediments;

7. contrary dips within the downlapping zones, which represent possible channeling and the formation of mounds or ridges.

Using the preceding criteria, reefal complexes were interpreted on line 122-6b (Fig. 6). They are graded as "probable" or "possible," depending on the extent to which they conform to the seven characteristics. In particular, if only a low-

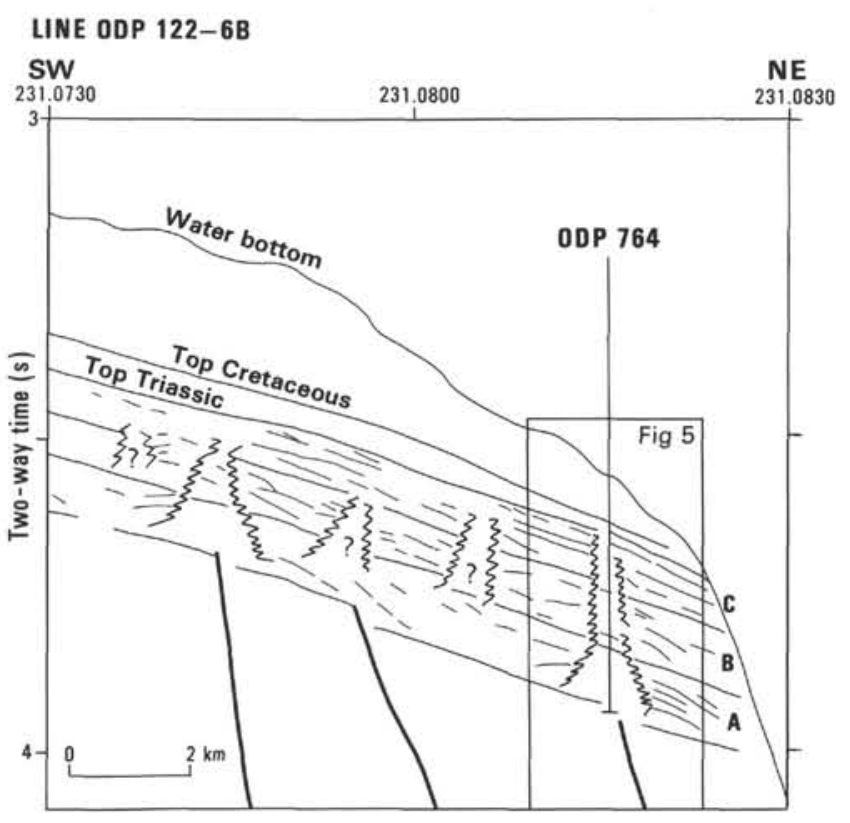

Figure 6. Line drawing of site survey line 122-6B in the region of Site 764 , showing interpreted reefal complexes and seismic sequences. 
reflectivity zone is present, the feature is designated as "possible." Three possible and one probable reefal complex are interpreted away from Site 764 . The probable feature is similar in horizontal dimensions and vertical development to the reefal complex at Site 764 and is developed on the top of an upthrown fault block. The three possible features are smaller and display only blanking of the seismic-reflection data (Fig. 6).

\section{Line 122-1}

Seismic features interpreted as probable and possible reefal complexes in the Rhaetian interval are also observed on ODP line 122-1 over the northeastern margin of the Wombat Plateau (Figs. 7 and 2). The zones of discontinuous seismic reflections, interpreted as reefal complexes in the northern deep-water part of the line, are wider at the base (up to $1.2 \mathrm{~km}$ in width) than this feature at Site 764 . Their maximum vertical development is less than $250 \mathrm{~ms}$ TWT. Adjacent to the interpreted reefal complexes, downlapping seismic facies alternate with facies composed of reflectors parallel to regional dip. Masking of seismic-reflection data below the interpreted reefal complexes occurs on the line and commonly obscures the underlying structure.

An example of the seismic characteristics associated with a probable reefal complex on this line is shown in Figure 8. A poorly reflective zone with discontinuous reflectors is interpreted as the reefal complex. Seismic events dip away from this zone. The wedges corresponding to the dipping events have a total thickness of approximately $200 \mathrm{~m}$ adjacent to the interpreted reefal core and extend for more than $2.0 \mathrm{~km}$ in either direction. Reversal of reflector dip within the upper wedge (sequence B) occurs just south of the interpreted reef core. Seismic events are largely absent immediately below the probable reefal complex, as at Site 764 .

\section{Line 122-3}

One possible and one probable reefal complex are interpreted on ODP Line 122-3 near Site 761 (Fig. 9). The features correspond to low-reflectivity zones thinning from base to apex. Events dip away from the zone in the case of the probable feature. These features are relatively small and are restricted to sequence $A$.

\section{Line 56/13}

BMR Line 56/13 was collected aboard RV Rig Seismic using two $500-\mathrm{m}^{3}$ Bolt air guns and a 48-channel Teledyne streamer. The frequency content of the data is lower than that of the water gun data described previously. Interpreted reefal complexes on this line correspond to zones of discontinuous reflectors. These are normally associated with the drape of higher reflectors and velocity pull-up of deeper reflectors. Detrital wedges or sediment ramps can be interpreted on the line, but are less well imaged because of the lower frequency content. Line 56/13 does, however, clearly show the characteristic dispersal of seismic energy below the reefal features (Figs. 10 and 11).

\section{SEISMIC SEQUENCE ANALYSIS}

Only three main seismic sequences in the Rhaetian interval can be delineated because of the relatively low frequency content and resolution of the seismic-reflection data; these are designated sequences $\mathrm{A}, \mathrm{B}$, and $\mathrm{C}$ from bottom to top. Subsequences can, however, be defined locally.

The sequence boundaries were mapped from line to line on the basis of seismic character because the low accuracy of the navigation meant that the lines did not tie.

\section{Sequence A}

On line 122-6B (Fig. 6), the lowest sequence, A, is approximately $100 \mathrm{~ms}$ TWT in thickness and is dominated by two-way dipping events similar to those associated with dipping events on either side of the reefal complex at Site 764 . At the western end of the line these events occur without any obvious association with reefal complexes. They could correspond to features associated with reefal complexes out of the plane of the section, or to channeling in a high-energy depositional environment.

The internal character of sequence $\mathrm{A}$ on line 122-1 (Figs. 7 and 8 ) is similar to that on line $122-6 \mathrm{~B}$. The unconformity at the top of sequence $\mathrm{A}$ is elevated within most of the interpreted reefal complexes, in some cases by up to as much as 30 ms TWT, suggesting that the unconformity at the top of sequence $\mathrm{A}$ is not severely erosional, that there has been some posterosional compaction of laterally equivalent sediment,

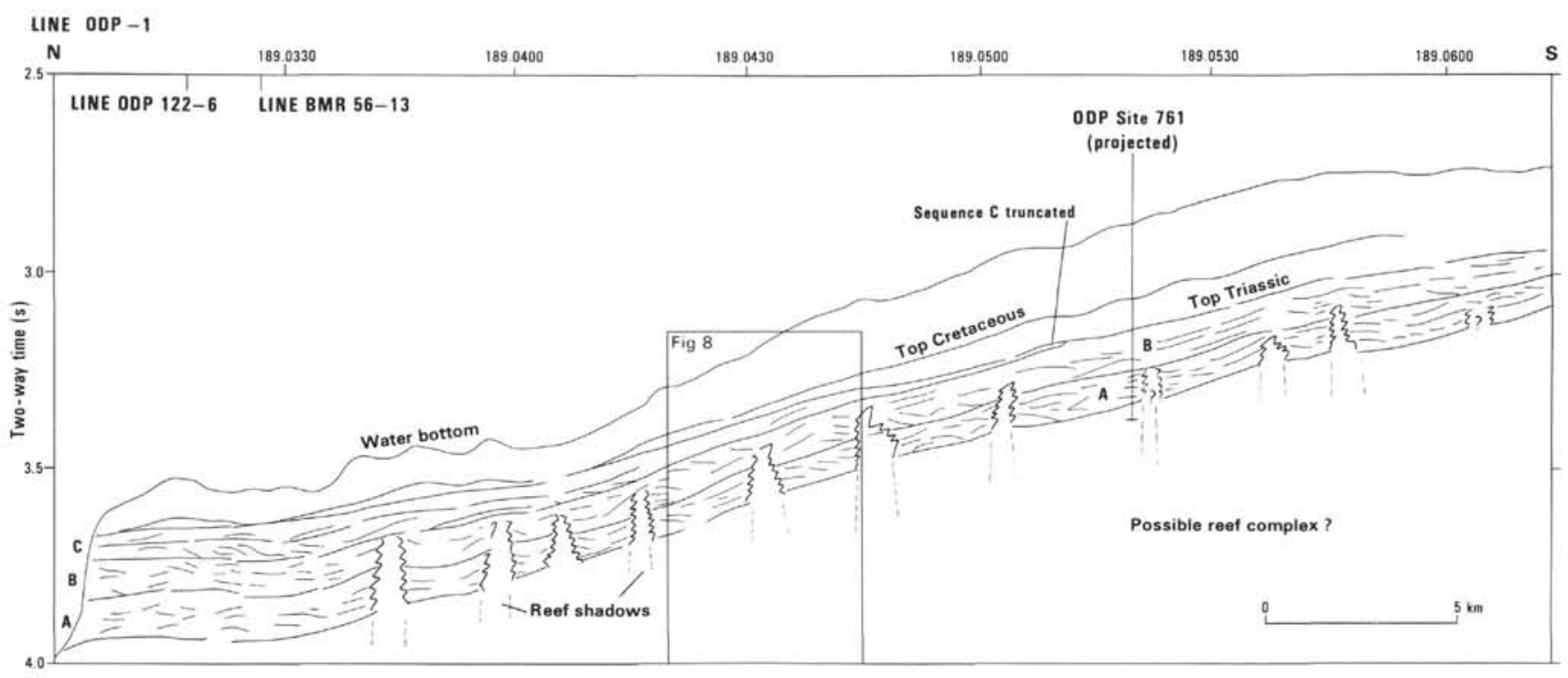

Figure 7. Line drawing of southeast-directed ODP line 122-1 on the eastern Wombat Plateau showing interpreted reefal complexes and seismic sequences as for Figure 6. Location shown in Figure 2. 


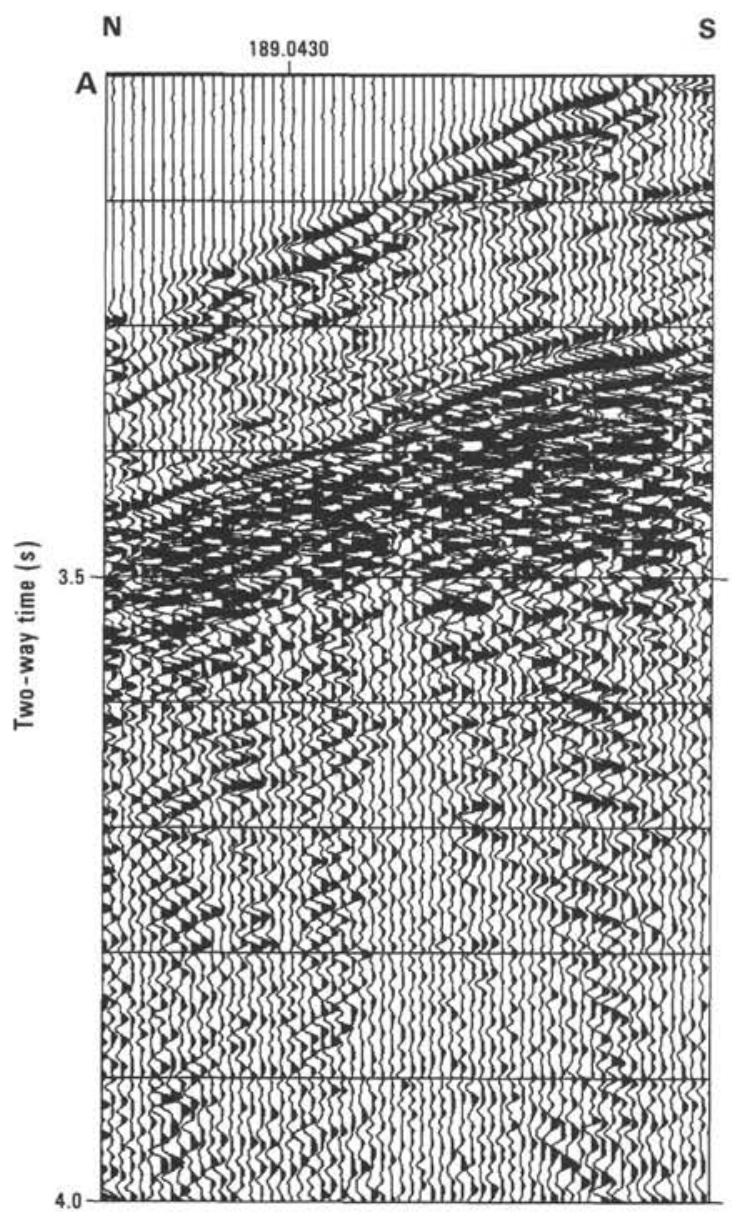

$\mathbf{N}$
S

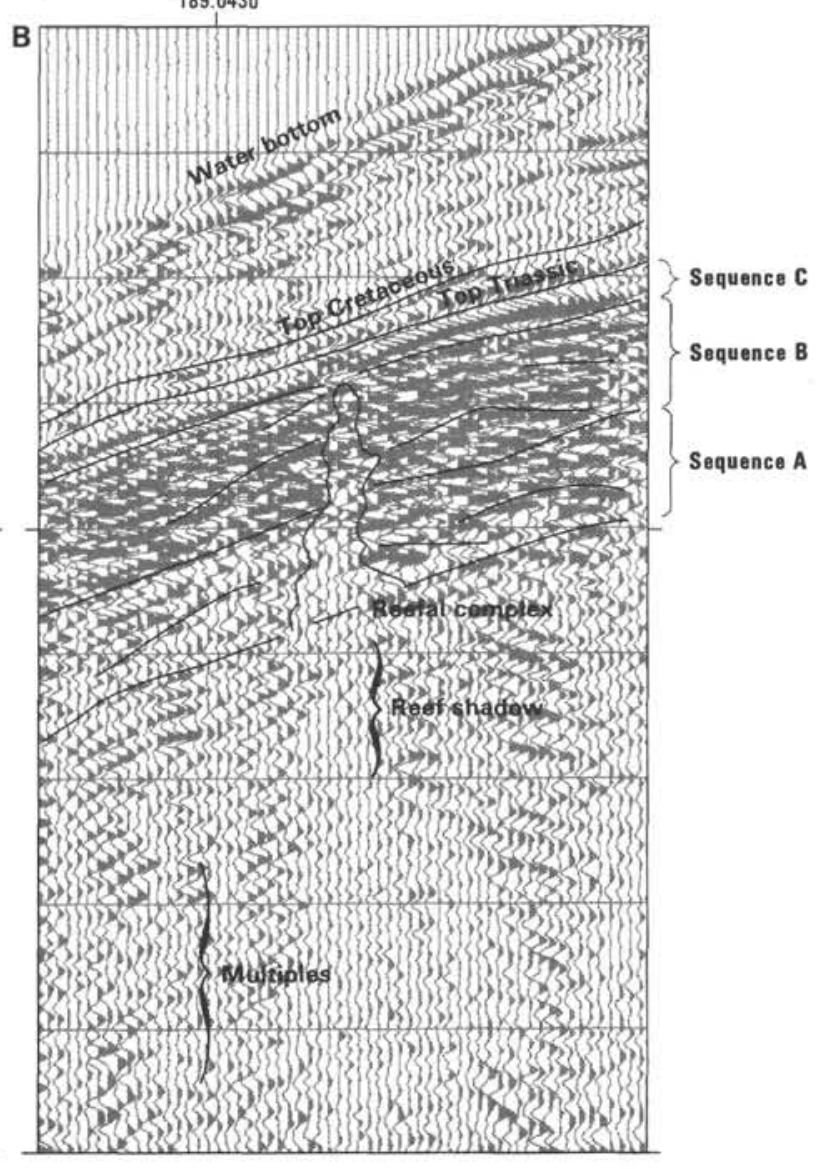

$4 \mathrm{~km}$

Figure 8. Uninterpreted (A) and interpreted (B) detail of an interpreted reefal complex on line 122-1 showing reefal complex and seismic sequences.

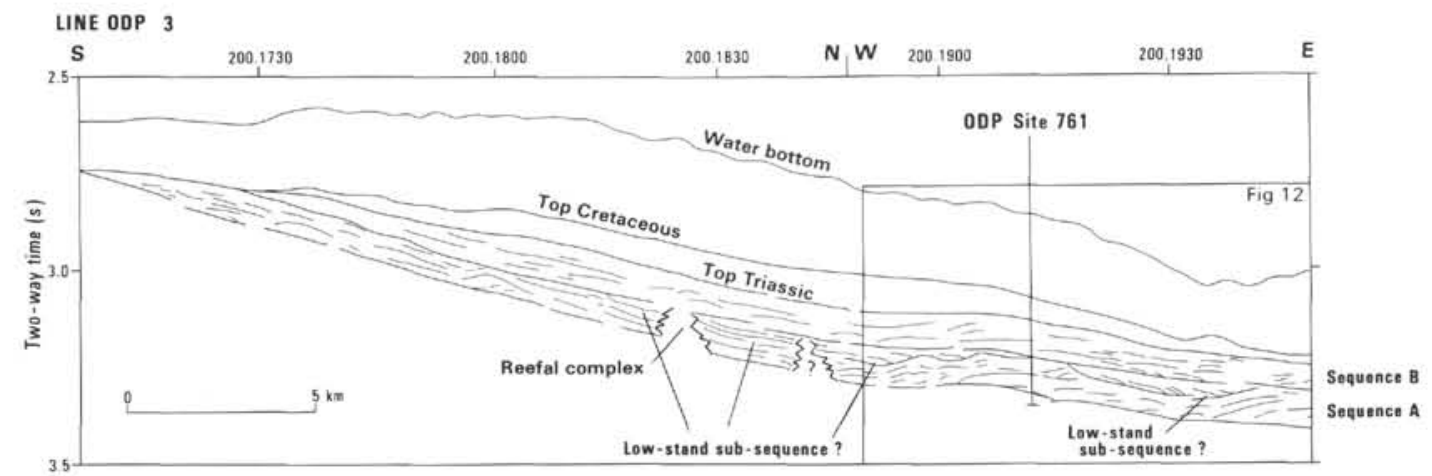

Figure 9. Line drawing of east-west ODP line 122-3 near Site 761 showing interpreted carbonate reefal complexes and seismic sequences. Location shown in Figure 2.

and/or that there is some velocity pull-up due to the overlying reefal section. The internal character of sequence A becomes more conformable south of Site 761. On line 122-1 all interpreted reefal complexes are developed throughout sequence $\mathrm{A}$, and some extend into sequence $\mathrm{B}$.

Line 122-3 ties Site 761 and intersects lines 122-1 and $56-13$. Sequence A is present near Site 761 , but is truncated between Sites 761 and 760 (Fig. 2). Sequence A has a thickness of approximately 100 ms TWT near Site 761 and continues to display some dip reversals in internal reflectors (Fig. 9), with one probable and one possible reefal complex. However, the internal character on the lines is always more conformable than that of sequence $A$ to the north and becomes progressively more conformable to the west of Site 761 prior to truncation between Sites 761 and 760 . A subsequence $30 \mathrm{~ms}$ TWT thick at the top of sequence $\mathrm{A}$ east and west of 


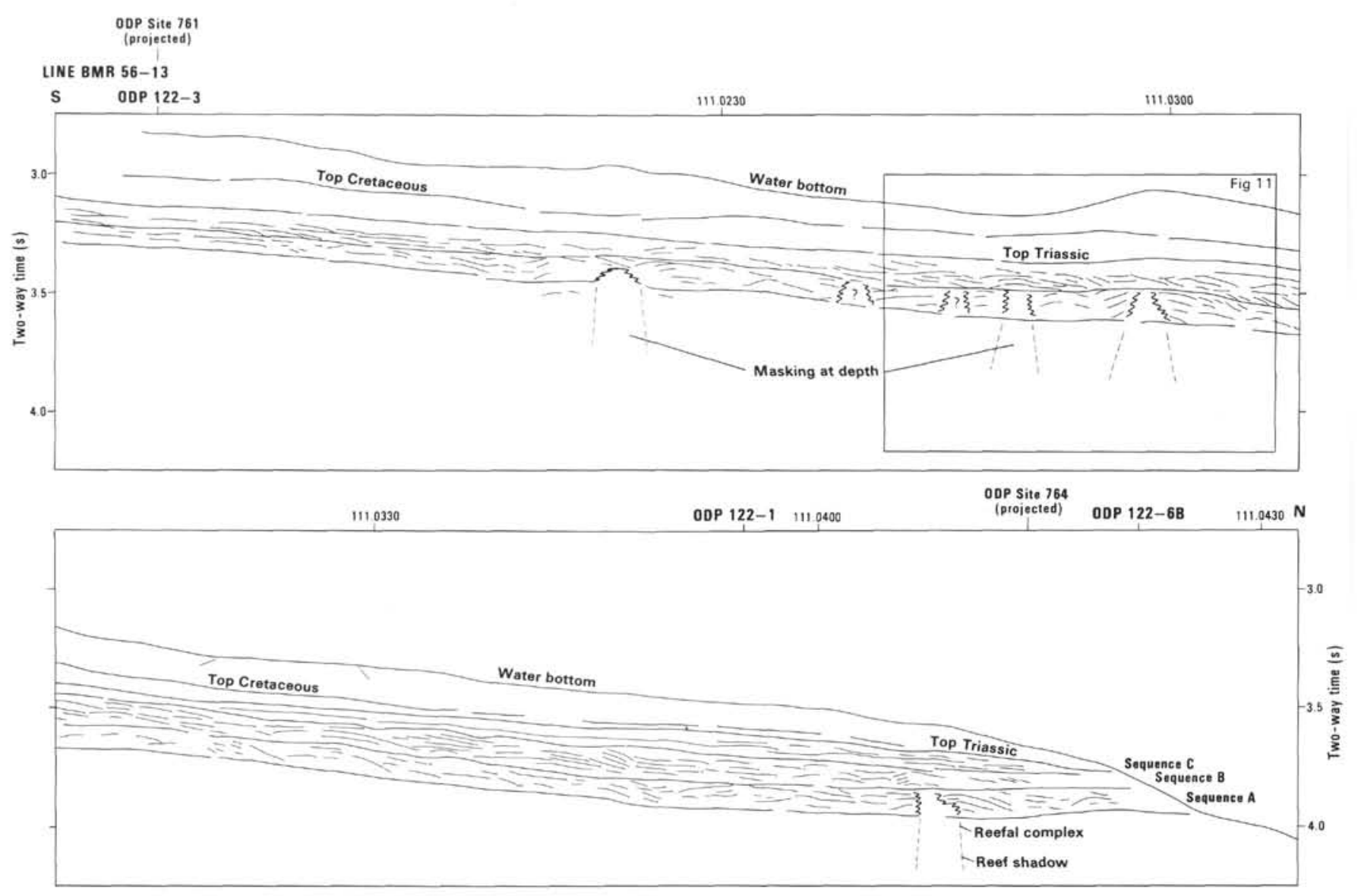

$2 \mathrm{~km}$

Figure 10. Line drawing of line 56-13 on the northern Wombat Plateau showing interpreted reefal complexes and seismic sequences.

Site 761 shows downlap onto an unconformity probably caused by channeling between two mounded features (Fig. 12). Site 761 drilled one of these mounds.

On line $56-13$, the tie with line $122-3$, sequence $A$ is internally conformable (Fig. 10). Mounding and blank zones interpreted as reefal complexes occur farther north (for example, 11.0300, Fig. 11). The seismic characteristics of sequence $\mathrm{A}$ observed in the air gun data of line 56-13 probably represent a lower frequency expression of the similar characteristics shown in the water gun data of lines $122-1$ and 122-6B.

\section{Sequence B}

Sequence B overlies sequence A. Near Site 764 on line 122-6B (Fig. 6), it displays events dipping away from interpreted reefal complexes, as in sequence A. The unconformity at the top of sequence B is angular and passes through all the probable and possible reefal complexes.

Sequence B on line 122-1 displays a similar internal character to that of sequence $A$ on line $122-6 \mathrm{~B}$, but internal reflectors become more conformable in character toward the south near Site 761 (Fig. 7), corresponding to a change in depositional environment. Reefal complexes penetrate into sequence B on the northern half of the line. Sequence B near Site 761 displays little mounding and relatively conformable internal reflectors. The conformable internal character of sequence B persists on line 122-3 except in the extreme east (Fig. 9). Sequence B is truncated by the erosional surface at the top of the Triassic at the western end of the line.
On line $56-13$ (Figs. 10 and 11), sequence B is approximately $100 \mathrm{~ms}$ TWT in thickness at the intersection of line 122-3 and reduces to $60 \mathrm{~ms}$ TWT near the northern scarp of the Wombat Plateau. The internal character is again dominantly conformable to the south near the intersection with line 122-3. It becomes progradational northward, but with some contrary dips. The progradation is generally to the north.

\section{Sequence C}

Sequence $\mathrm{C}$ overlies sequence B; it varies in thickness on line $122-6 \mathrm{~B}$ from $100 \mathrm{~ms}$ TWT in the west to $60 \mathrm{~ms}$ TWT in the east (Fig. 6). Sequence $C$ can be divided into three subsequences toward the eastern end of the line, of which the upper two are relatively thin. The uppermost subsequence, which probably corresponds to the transgressive facies at Site 764, appears to be truncated west of Site 764 , but the seismic resolution is insufficient to define details of the truncation. The internal character of the subsequences of sequence $C$ is dominantly progradational to the east. Some reefal complexes on line $122-6 \mathrm{~B}$ extend into the lower subsequences of sequence $C$, but none penetrate the uppermost subsequence.

On line $122-1$, the lowest subsequence of sequence $C$ is progradational to the north near Site 764 (Fig. 7). Some dips to the south occur, however, south of a doming in the base of the sequence above a reefal complex near 189.0400. The internal character of the two, thin upper subsequences of sequence $\mathrm{C}$ is not observable on the line. Sequence $C$ is truncated to the south before the intersection with line 122-3, but details of the truncation are difficult to define because of the strong multi- 
A s

111.0300

N

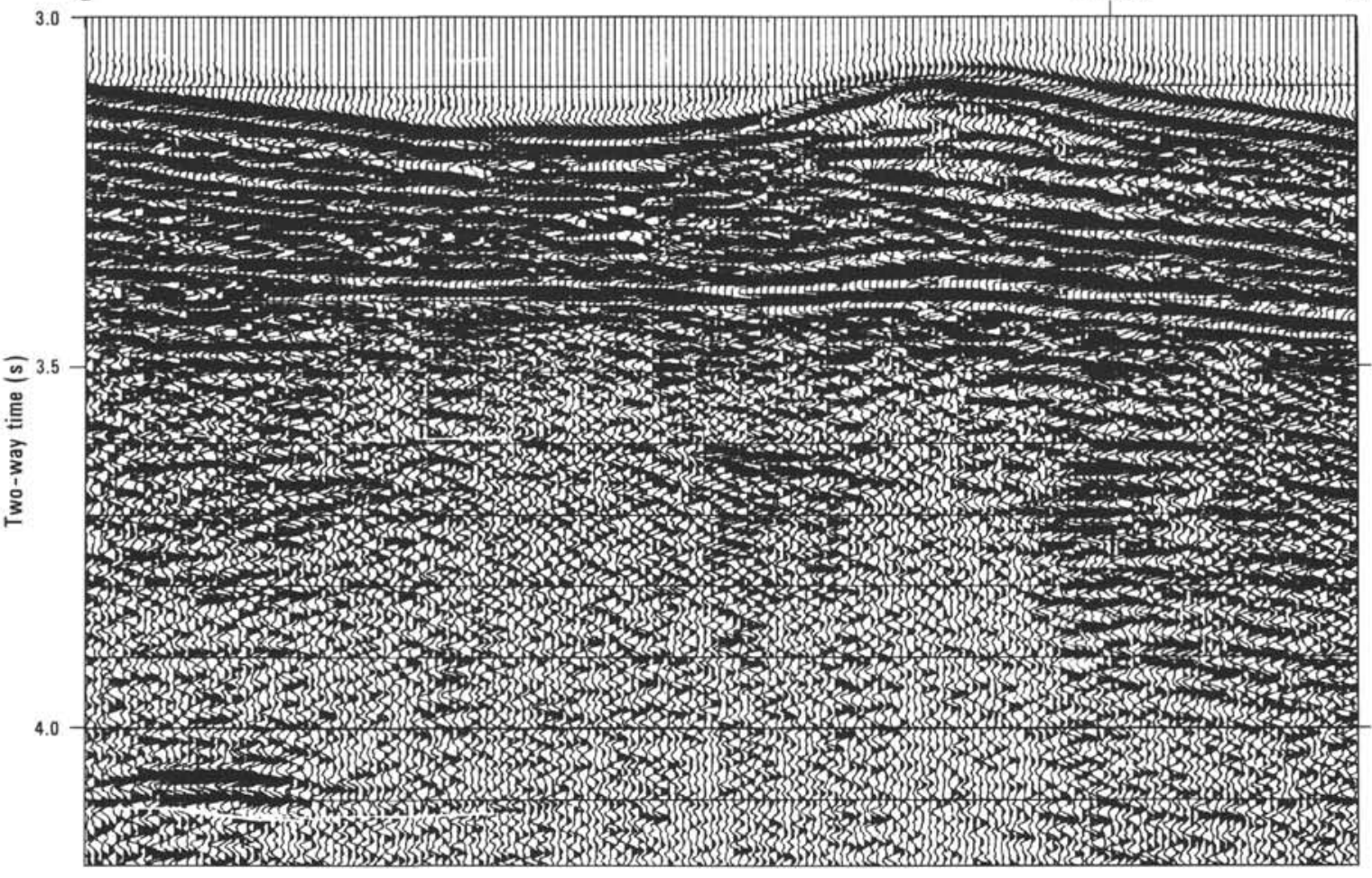

B s

111.0300

$\mathbf{N}$

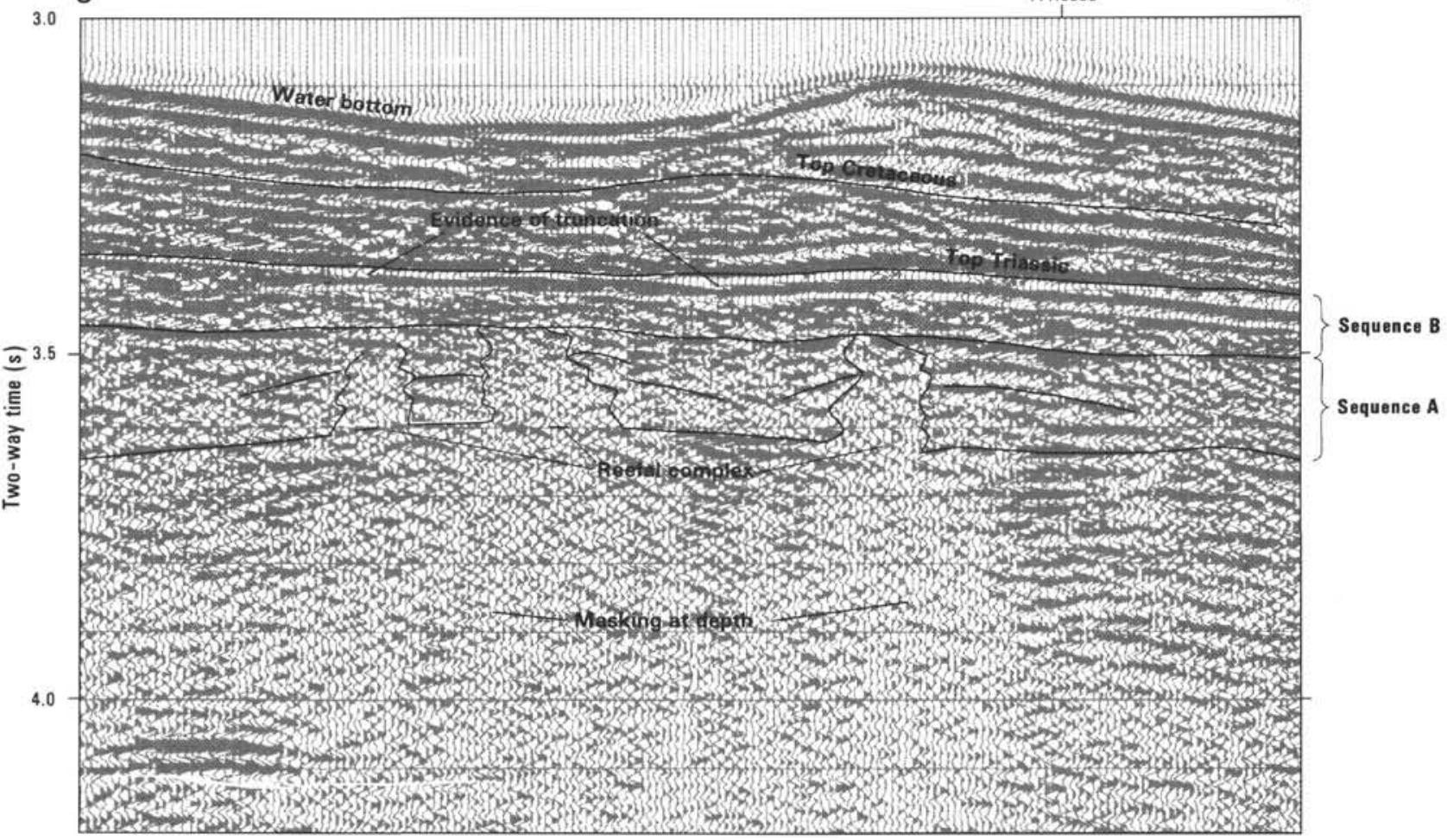

$2 \mathrm{~km}$

Figure 11. Uninterpreted (A) and interpreted (B) example of seismic-reflection data from line 56-13 showing seismic sequences and masking of seismic events below interpreted reefal complexes. Seismic evidence for truncation of sequence B is also shown. 


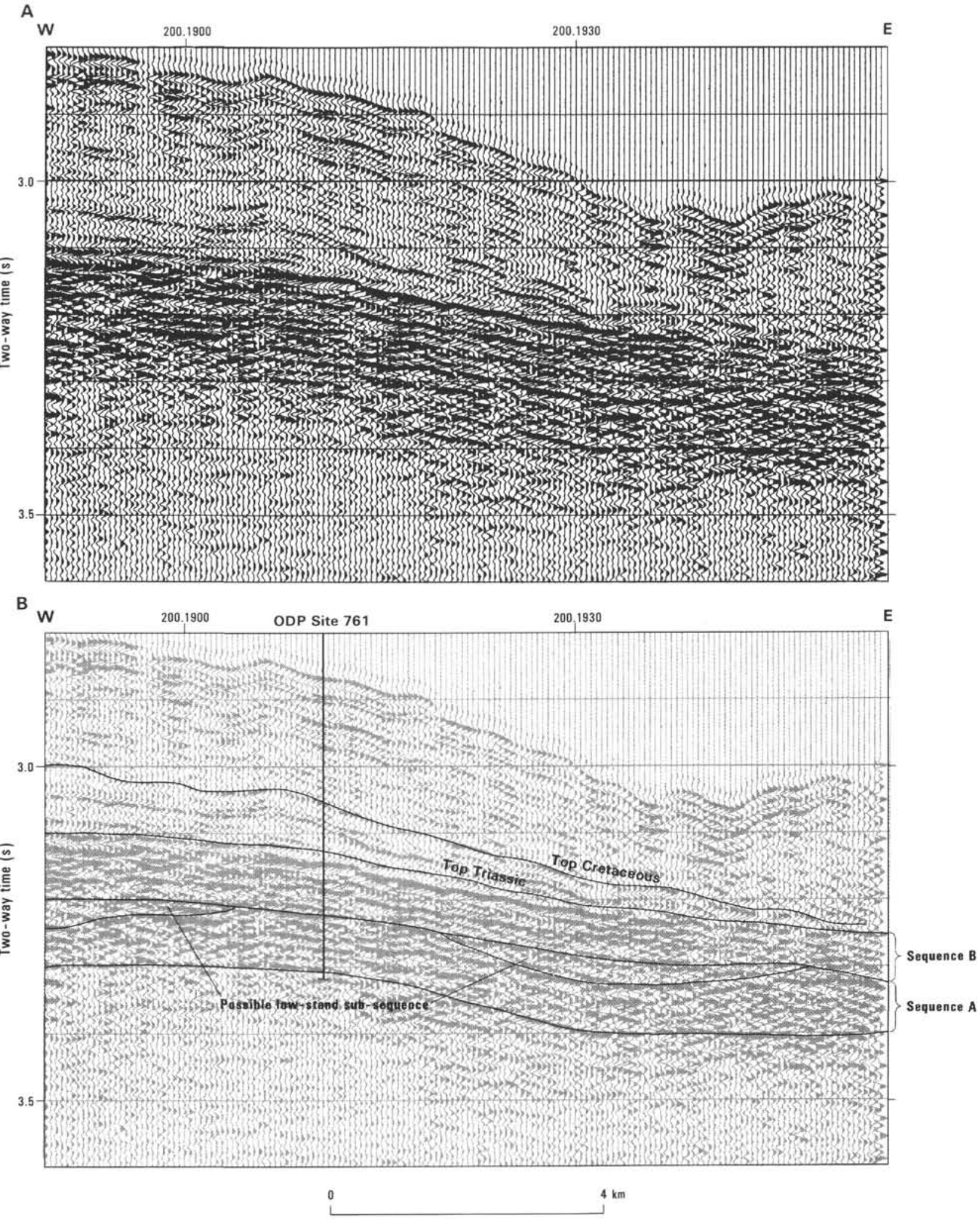

Figure 12. Uninterpreted (A) and interpreted (B) example of possible lowstand subsequence at the top of sequence A on line 122-3 near Site 761. Note how events downlap onto the unconformity corresponding to the top of the adjacent mounded features. 
cyclical seismic event associated with the large contrast in acoustic impedances between the Cretaceous and younger oozes and chalks and the Triassic limestones.

On line 56-13 (Fig. 10) sequence $\mathrm{C}$ is eroded in the south, but is interpreted to be present near 111.0310 and to thicken northward to approximately $80 \mathrm{~ms}$ TWT. Good evidence for truncation rather than depositional thinning of the Rhaetian section between Sites 764 and 761 can be seen in Figure 11 where the breaks in the seismic horizon corresponding to the strong top Triassic reflector probably indicate substantial truncation of the Upper Triassic strata. In the north, two subsequences can be defined. Their internal character is obscure because of the low frequency content of the seismic record, but it appears to consist of gently dipping events dominantly progradational to the north.

\section{DISCUSSION}

The style of reefal development on the margin of the carbonate platform on the Wombat Plateau appears to consist dominantly of individual reefal complexes, possibly roughly circular in plan, implying a pinnacle reef margin (Playford, 1984). The distribution of the interpreted reefal complexes is shown on Figure 2.

In the north, the seismic facies of sequences A and B are complex, and the interpretation of shipboard data at Site 764 assigns an open marine environment to strata corresponding to both sequences A and B (Haq, von Rad, O'Connell, et al., 1990). Near Site 761 , the reflectors become progressively more conformable in sequence $\mathrm{B}$, suggesting a change in the environment of deposition. The interpreted sequence boundary corresponds to a strong change in the logging data at Site 761 , particularly with regard to silica to aluminium ratios (Fig. 13), probably reflecting a greater abundance of quartz grains compared with clay (Haq, von Rad, O'Connell, et al., 1990), which implies a systematic variation in the transport of terrigenous clastics into the depositional area (N. Exon, pers. comm., 1990). The ratios are higher for sequence A and lower for sequence B. The strata at Site 761 corresponding to sequences $\mathrm{A}$ and $\mathrm{B}$ are interpreted as open marine and lagoonal, respectively, from the shipboard data (Haq, von Rad, O'Connell, et al., 1990). This is consistent with the different internal seismic characters of sequences A and B in the region of Site 761 .

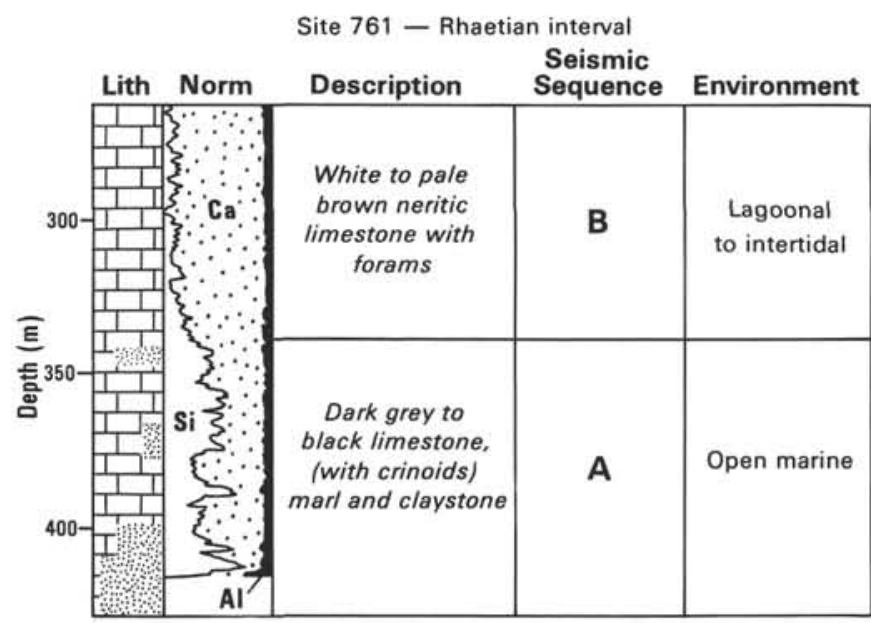

Figure 13. Well log and lithologic expression of change from open marine to lagoonal environments (sequences A to B) at Site 761. The sharp decrease in the silica to calcium ratio indicates less access to terrigenous clastics.
Reef growth is interpreted to occur above the unconformity corresponding to the top of sequence $\mathrm{A}$ in the far north, but rarely in the south. Reef growth also occurs into sequence $\mathrm{C}$ in the far north, where the internal character is generally progradational. At Site 764 sequence C corresponds to an open marine interval.

Seismic sequence A appears from the geological evidence from Sites 761 and 764 (von Rad et al., this volume) to correspond in the sequence stratigraphic sense to a transgressive sequence with reef growth using the space formed by the transgression. A possible relative lowstand subsequence of sequence $\mathrm{A}$ is developed locally in the south on line $122-3$, as indicated by downlapping events, which probably correspond to infilling of channels between mounded features (Fig. 12). The subsequence infills locally up to the unconformity at the base of sequence B. This subsequence is not observed at the top of sequence A in the north. This could indicate that, in the north, the relative lowstand sediments were not deposited or retained in depressions on the carbonate platform but were distributed to lower energy environments either in the fore or back reef.

Sequence B, based on the geological evidence from Sites 761 and 764 (von Rad et al., this volume), could represent a highstand systems tract. Sequence $C$ appears to prograde to the northeast, and on geological grounds could represent a transgressive systems tract. All three sequences are truncated to the south so that Sites 759 and 760 drilled Norian and Carnian sediments, but no Rhaetian sediments. The locations of truncation of the sequences are shown in Figure 2.

The interpreted worldwide eustatic component of sea-level change shows progressively higher sea levels with time through the Rhaetian (Haq et al., 1988). The seismic sequence stratigraphy of the carbonate platform on the Wombat Plateau suggests that the combination of the eustatic and tectonic subsidence components of sea-level rise during the Rhaetian may have been more complex. The overall data set within the Rhaetian is not sufficiently detailed or extensive to define this local sea-level history other than qualitatively.

Understanding of the Rhaetian reefal carbonate platform on the Wombat Plateau is still in its early stages, but will be greatly enhanced when the more detailed and higher resolution water gun data set collected aboard the BMR's Rig Seismic from the Wombat Plateau during a May 1990 cruise becomes available.

\section{CONCLUSIONS}

The samples from Site 764 , combined with a seismic facies interpretation of the regional seismic-reflection data, indicate that it is likely that a major Late Triassic carbonate reefal platform with pinnacle reefs developed in tropical waters on the Wombat Plateau at the northern edge of the Exmouth Plateau. Carbonate platforms of similar age also developed elsewhere around the margins of the ancient Tethyan Ocean, and it appears that large areas of the Australian Northwest Shelf were ideally placed for the development of Late Triassic carbonate reefal platforms (Williamson et al., 1989).

Comparison to the seismic characteristics of the reefal complex at Site 764 allowed interpretation of the presence of complexes away from the site. These characteristics are

1. a zone of low reflectivity corresponding to the complex;

2. velocity pull-up beneath the complex;

3. blanking of seismic energy below, producing a reef shadow;

4. positive relief above the complex;

5. location above a paleohigh; 
6. downward-dipping events around the seismically dead zone, probably corresponding to sedimentary or detrital wedges;

7. some reversed dips possibly related to channeling within the wedges near the complex.

The internal characteristics of the three main seismic sequences corresponding to the Rhaetian interval in the region of Sites 764 and 761 can be related to the development of reefal complexes and to the depositional environment. The drilling results at Sites 764 and 761 indicate an open marine environment in sequence $\mathrm{A}$ time. This is consistent with the more chaotic seismic character in sequence $\mathrm{A}$, associated with the growth of reefal complexes and channeling. In the southeast, near Site 761, results indicate that the environment was lagoonal in sequence B time, which is also consistent with the conformable seismic character of sequence B. Sequence C is present only in the north. Near Site 764, reefal complexes are interpreted through all three sequences. Geological data from Sites 761 and 764 suggest that sequence $A$ may represent a transgressive systems tract, whereas sequences B and C may correspond to highstand and transgressive systems tracts.

\section{ACKNOWLEDGMENTS}

The paper was reviewed by Phil Symonds, David Feary, and Neville Exon of the Bureau of Mineral Resources, Australia. The contributions of the SEDCO drilling crew, the ODP technical staff, and the captain and crew of JOIDES Resolution during Leg 122 are gratefully acknowledged. Leg 122 seismic-reflection data were processed at BMR by Simon Kravis, and the figures were drawn there. This paper is published with the permission of the Director, Bureau of Mineral Resources.

\section{REFERENCES}

Bain, J.H.C., Mackenzie, D. E., and Ryburn, R. J., 1975. Geology of the Kubor Anticline-Central highlands of Papua New Guinea. Bull.-Bur. Miner. Resour. Geol. Geophys. Aust., 155.

Barber, P. M., 1982. Paleotectonic evolution and hydrocarbon genesis of the central Exmouth Plateau. APEA J., 22:131-144.

1988. The Exmouth Plateau deep water frontier: a case history. In Purcell, P. G., and Purcell, R. R. (Eds.), The North West Shelf, Australia: Proc. Pet. Expl. Soc. Aust. Symp., 173187.

Bosellini, A., 1989. Dynamics of Tethyan carbonate platforms. In Crevelto, P. D., Wilson, J. L., Sarg, F., and Read, J. F. (Eds.), Controls on Carbonate Platform and Basin Development. Spec. Publ. Soc. Econ. Paleontol. Mineral., 44:3-14.

Davies, P. J., Symonds, P. A., Feary, D. A., and Pigram, C. J., 1988. Facies models in exploration-the carbonate platforms of northeast Australia. APEA J., 28:123-43.

1989. The evolution of the carbonate platforms of northeast Australia. Spec. Publ. Soc. Econ. Paleontol. Mineral., 44:233258.

Exon, N. F., and Willcox, J. B., 1978. Geology and petroleum potential of the Exmouth Plateau area off Western Australia. AAPG Bull., 62:40-72.

1980. The Exmouth Plateau: stratigraphy, structure and petroleum potential. Bull. Bur. Miner. Resour. Geol. Geophys. Aust., 199.

Exon, N. F., and Williamson, P. E., 1988. Preliminary post-cruise report, Rig Seismic research cruises 7 \& 8: sedimentary basin framework of the northern and western Exmouth Plateau. Bur. Min. Resour. Aust. Rec., 1988/30.

Exon, N. F., Williamson, P. E., von Rad, U., Haq, B. U., and O'Connell, S., 1989. Ocean drilling finds Triassic reef play off NW Australia. Oil \& Gas J., 87:46-52.

Falvey, D. A., and Mutter, J. C., 1981. Regional plate tectonics and the evolution of Australia's passive continental margins. BMR J. Aust. Geol. Geophys., 6:1-29.
Falvey, D. A., and Veevers, J. J., 1974. Physiography of the Exmouth and Scott Plateau, Western Australia, and adjacent northeast Wharton Basin. Mar. Geol., 17:21-59.

Flügel, E., and Stanley, G. D., 1984. Reorganization, development and evolution of post-Permian reefs and reef organisms. Palaeontogr. Amer., 54:177-186.

Haq, B. U., Hardenbol, J., and Vail, P. R., 1988. Mesozoic and Cenozoic chronostratigraphy and cycles of sea-level change. In Wilgus, C. K., Hastings, B. S., Kendall, C. G., Posamentier, H. W., Ross, C. A., and Van Wagoner, J. C. (Eds.), Sea-Level Change-An Integrated Approach. Soc. Econ. Paleontol. Mineral. Spec. Publ., 42:71-108.

Haq, B. U., von Rad, U., O'Connell, S., et al., 1990. Proc. ODP, Init. Repts., 122: College Station, TX (Ocean Drilling Program).

Kharmov, A. N., 1987. Palaeomagnetology: Berlin (Springer Verlag).

Larson, R. L., 1977. Early Cretaceous breakup of Gondwanaland off Western Australia. Geology, 5:57-60.

Larson, R. L., Mutter, J. C., Diebold, J. B., Carpenter, G. B., and Symonds, P., 1979. Cuvier Basin: a product of ocean crust formation by Early Cretaceous rifting off Western Australia. Earth Planet. Sci. Lett., 45:105-114.

Mutter, J. C., Larson, R. L., and Northwest Australia Study Group, 1989. Extension of the Exmouth Plateau, offshore northwestern Australia: deep seismic reflection/refraction evidence for simple and pure shear mechanisms. Geology, 17:15-18.

Pigram, C. J., and Panggabean, H., 1984. Rifting of the northern margin of the Australian continent and the origin of some microcontinents in Eastern Indonesia. Tectonophysics, 107:331-353.

Playford, P. E., 1984. Platform margin and marginal slope relationships in Devonian reef complexes of the Canning Basin, Western Australia. Geol. Soc. Aust. and Pet. Explor. Soc. Aust., Canning Basin Symp., Perth, 1984, 258-271.

Powell, D. E., 1976. The geological evolution of the continental margin off northwest Australia. APEA J., 16:13-23.

Sarg, F. R., 1988. Carbonate sequence stratigraphy. In Wilgus, C. K., Hastings, B. S., Kendall, C. G., Posamentier, H. W., Ross, C. A., and Van Wagoner, J. C. (Eds.), Sea-Level Change: An Integrated Approach. Spec. Publ. Soc. Econ. Paleontol. Mineral., 42:155181.

Scotese, C. R., 1986. Phanerozoic reconstructions: a new look at the assembly of Asia. Univ. Texas Inst. Geophys. Tech. Rep., 66.

Şengör, A.M.C., 1985. The story of Tethys: how many wives did Okeanos have? Episodes, 8:3-12.

Skwarko, S. K., Nicoll, R. S., and Campbell, K.S.W., 1976. The Late Triassic molluscs, conodonts, and brachiopods of the Kuta Formation, Papua New Guinea. BMR J. Aust. Geol. Geophys., 1:219-230.

Stanley, G.D.R., 1987. Travels of an ancient reef. Nat. Hist., 11/ $87: 36-43$

Tjokrosapoetra, S., and Budhitrisna, T., 1982. Geology and tectonics of the northern Banda Arc. Bull. Geol. Res. Dev. Cent. (Bandung, Indones.), 6:1-17.

Veevers, J. J., and Cotterill, D., 1979. Western margin of Australia: a Mesozoic analogue of the East Africa rift system. Geology, 7:713-717.

Veevers, J. J., and Johnstone, M. H., 1974. Comparative stratigraphy and structure of the western Australian margin and the adjacent deep ocean floor. In Veevers, J. J., Heirtzler, J. R., et al., Init Repts. DSDP, 27: Washington (U.S. Govt. Printing Office), 571585.

von Rad, U., and Exon, N. F., 1983. Mesozoic-Cenozoic sedimentary and volcanic evolution of the starved passive continental margin off northwest Australia. In Watkins, J. S., and Drake, C. L. (Eds.), Studies in Continental Margin Geology: AAPG Mem., 34:253281.

von Stackelberg, U., Exon, N. F., von Rad, U., Quilty, P., Shafik, S., Beiersdorf, H., Seibertz, E., and Veevers, J. J., 1980. Geology of the Exmouth and Wallaby plateaus off northwest Australia: sampling of seismic sequences. BMR J. Aust. Geol. Geophys., 5:113140.

Willcox, J. B., 1982. Petroleum prospectivity of Australian marginal plateaus. AAPG Stud. Geol., 12:245-272.

Willcox, J. B., and Exon, N. F., 1976. The regional geology of the Exmouth Plateau. APEA J., 16:1-11. 
Williamson, P. E., Exon, N. F., Haq, B. U., von Rad, U., O'Connell, S., and Leg 122 Shipboard Scientific Party, 1989. A Northwest Shelf Triassic reef play: results from ODP Leg 122. APEA J., 29:328-344.

Williamson, P. E., and Falvey, D. A., 1988. Preliminary post-cruise report, Rig Seismic research cruises 7 and 8: deep seismic structure of the Exmouth Plateau. BMR Geol. Geophys. Rec., 1988/31.

Williamson, P. E., and Shipboard Scientific Party, 1990. Underway geophysics. In Haq, B. U., von Rad, U., et al., Proc. ODP, Init. Repts., 122: College Station, TX (Ocean Drilling Program), 39-77.

Williamson, P. E., Swift, M. G., Kravis, S. P., Falvey, D. A., and Brassil, F., 1990. Permo-Carboniferous rifting of the Exmouth
Plateau region, Australia: an intermediate plate model. In Pinet, B., and Bois, C. (Eds.), The Potential of Deep Seismic Profiling for Hydrocarbon Exploration: Paris (Editions Technip), 235-248. Wright, A. J., and Wheatley, T. J., 1979. Trapping mechanisms and the hydrocarbon potential of the Exmouth Plateau, Western Australia. APEA J., 19:19-29.

Date of initial receipt: 30 March 1990

Date of acceptance: 22 March 1991

Ms 122B-126 